\title{
Review Article \\ Opportunities and Challenges for Pastoral Beef Cattle Production in Ethiopia
}

\author{
Belete Kuraz Abebe $(\mathbb{D}$, Mulugeta Tesfaye Alemayehu, and Sharew Mekonnen Haile \\ Department of Animal Science, Werabe University, P.O. Box 46, Werabe, Ethiopia \\ Correspondence should be addressed to Belete Kuraz Abebe; beleab2@gmail.com
}

Received 22 December 2021; Revised 26 January 2022; Accepted 2 February 2022; Published 28 February 2022

Academic Editor: Xinqing Xiao

Copyright $(2022$ Belete Kuraz Abebe et al. This is an open access article distributed under the Creative Commons Attribution License, which permits unrestricted use, distribution, and reproduction in any medium, provided the original work is properly cited.

The beef cattle production sector plays a crucial role in the livelihoods of pastoral farmers in Ethiopia, and it is the main source of beef animals for domestic and foreign markets. As compared to other African countries, Ethiopia has a huge beef cattle population (65.35 million heads). However, the quality and quantity of beef, as well as per capita meat consumption of Ethiopians, are very low $(8.4 \mathrm{~kg} /$ individual/year). In this sense, the goal of this review was to provide and synthesize the most validated scientific information on the opportunities and challenges for pastoral beef cattle production in Ethiopia. The potential for pastoral beef cattle producers in Ethiopia included population growth, urbanization, literacy, and family income, as well as high demand for beef animals in domestic and foreign markets. In contrast, problems with beef cattle production systems, diseases, shortages of feed and water, lack of veterinary services, droughts, lack of market access and infrastructure, illegal animal trades, and poor genetic potential of indigenous cattle are among the limiting factors that hamper efficient beef production in the country. In Ethiopia, the yield and compositional quality of beef are very low compared to other African countries and the global market in general. Therefore, empowering pastoral beef cattle producers will help us to supply high quality and quantity of beef and will ensure sustainable beef cattle production with an identified market destination and access.

\section{Introduction}

Livestock production has a considerable contribution to the economy of Ethiopia and plays a vital role in providing export commodities like meat and meat products, live animals, hides and skins, and leather products to earn foreign currency [1]. Although the country is gifted with a very high potential for livestock resources, the sector's contribution to the national economy is much lower than its production potential [2]. The beef cattle production sector is critical to the livelihoods of pastoral farmers in Ethiopia, providing income, food, draught power, and a common asset for households $[3,4]$. The total number of cattle in the country is estimated to be 65.35 million heads, which is the highest in Africa [1]. Among these, 99.4\% of the total cattle in the country are local breeds. The proportion of hybrid and exotic breeds is too small, at only $0.58 \%$ and $0.07 \%$, respectively. One-fourth of cattle aged between 3 and 10 years are used for draught purposes, while the percentage of beef cattle (i.e., cattle reared exclusively for meat) is about $0.72 \%$
$[5,6]$. Despite the fact that there are a huge number of cattle in Ethiopia, the contribution of the sector to earning foreign currency and total gross domestic product (GDP) is still very low [7].

On the other hand, since there are no or little improved beef cattle breeds and production systems in Ethiopia, the yield and compositional quality of beef are very low compared to other African countries [8]. The cattle breeds in the country are multipurpose types, with the majority found in the traditional highland practices [9]. The current or existing beef cattle production systems in Ethiopia are traditional highland practices (mixed crop-livestock production system), by-product fattening, and Hararghe fattening systems [10, 11]. Despite the fact that Ethiopia has a large beef cattle population compared to other African countries, the average per capita meat consumption of Ethiopians is very low ( $8.4 \mathrm{~kg} /$ individual/year), and the beef produced in the country is not of high quality [10]. In this regard, numerous pastoral beef cattle producers sell their animals when they need money or a drought hits [12-14]. 
Consequently, the majority of pastorals do not consider the live beef animal trade as a profitable enterprise or a small business segment, and they do not pay attention to beef cattle husbandry practices that could increase their animal market value. In general, pastoral beef cattle producers in Ethiopia do not consider beef cattle production as their primary objective, but dairy production [15].

As a result, Ethiopia's beef productivity is $110 \mathrm{~kg} / \mathrm{head}$, which is around $25-30 \%$ lower than other East African countries $(143 \mathrm{~kg} / \mathrm{head})$ or the continental average $(156 \mathrm{~kg} / \mathrm{head})$, whereas the global average is $212 \mathrm{~kg} / \mathrm{head}$ [16]. Furthermore, in many sections of the country, pastoral cattle producers constitute the primary supply of beef animals for domestic and international markets. Several studies on the productivity of beef cattle have been undertaken in the past in various parts of the country [16]. However, in Ethiopia, the limiting reasons and potential for a sustainable beef export marketing system, as well as the degree of competitiveness with domestic and worldwide demand, have not been well investigated and gathered [17]. In this regard, multiple researches have been undertaken in various parts of the country in order to identify the potentials and limitations of farmers' beef cattle fattening operations. However, the opportunities and challenges for pastoral beef cattle production have not been thoroughly investigated or collated. Therefore, the goal of this review was to provide and synthesize scientifically validated and up-to-date information on the potentials and challenges for pastoral beef cattle production in Ethiopia with the following specific objectives:

(i) To outline the opportunities for pastoral beef cattle production

(ii) To identify the challenges for pastoral beef cattle production

\section{Review Method}

This review is based on theories and empirical findings, with saturated information extracted. Experiments and scientific findings were utilized to filter data and focus on recent publications. The period of search for this script is from January 10, 2021, to March 30, 2021. The script's literature search focused primarily on the challenges and opportunities for pastoral beef cattle production in Ethiopia. The information provided by Google Scholar, as well as peer-reviewed major indexers such as Web of Science, PubMed, and Scopus, was used to extract useful information during this review script. Thus, keywords such as "opportunities and challenges for pastoral beef cattle production" were used to find journal articles, papers, books, and symposia. The next section of this script will go through some concepts and experimental settings from the perspectives of pastoral beef cattle production opportunities and pastoral beef cattle production challenges in Ethiopia.

\subsection{Opportunities for Pastoral Beef Cattle Production}

2.1.1. Domestic and Foreign Demand for Beef Cattle. According to several studies, Ethiopians' demand for beef is increasing over time due to population growth, urbanization, literacy, and family income [9, 18-20]. Meat consumption is an excellent indicator of a person's economic position, and people in higher social classes have a stronger demand for high-quality meat products [21]. This might be a huge win for small-scale beef cattle producers across the country. Furthermore, local butchers and abattoirs in Ethiopia have a significant demand for beef animals in order to maintain a steady supply of high-quality live animals and to meet the needs of their customers, among other things, in order to improve their efficiency and competitiveness. In addition, the government earns foreign currency through exporting live cattle animals, particularly red meat, to the Middle East and other African countries $[22,23]$. According to FAO [24], meat demand in low- and middle-income countries will rise by 80 percent by 2030 and more than 200 percent by 2050 . This is owing to the high population growth rate [25]. According to Thornton [26], the demand for livestock goods such as milk, meat, and eggs is fast increasing in Ethiopia because the majority of livestock products are derived from pastoral farmers [3]. According to Ameha's [27] research, the export sector has a significant influence over the meat and live animal industries. The number of contemporary livestock product sector firms developed in the country, particularly meat export firms, has been expanding, as has the capacity of domestic abattoirs, the amount of meat exported, and the hard currency earned from this industry (meat) [28].

Furthermore, the country's enormous cattle population of various breeds, as well as the country's few legal live animal and meat exporters, provides further chances for beef cattle fattening enterprises, which mostly acquire beef cattle from pastoralists and pastoral farmers [3]. According to the Ethiopian tax and customs administration, live animal exports accounted for $70 \%$ of revenues in 2010, while meat exports accounted for 30\%. Cattle accounted for $46 \%$ of the total exported live animals and contributed to 67 percent of the cash earned. There is also the chance of expanding to Asian countries like Malaysia, where hall-slaughtered, frozen, skin-off corpses are required, and hygiene laws are less rigorous [29]. The volume of meat and meat products exported by Ethiopia during the last five years was varied from 2014 to 2018 . These variations might be due to drought, diseases, and illegal trade. Even though there were occasional variations, the volume of meat and meat products exported increased from $2013 / 14$ to $2017 / 18$, according to the data given in Figure 1.

2.1.2. Socioeconomic Importance of Beef Cattle. Animal husbandry practices make a substantial contribution to improving pastoral food security, particularly for pastoralists who rely entirely on their livestock [4]. Beef cattle farming employs 12.5 million people (70 percent of the total population) [24]. The sector also provides social and cultural value, adds to environmental values, and supports the rural community's livelihood by providing jobs, maintaining food security, and generating revenue [31]. Even if the industry's 


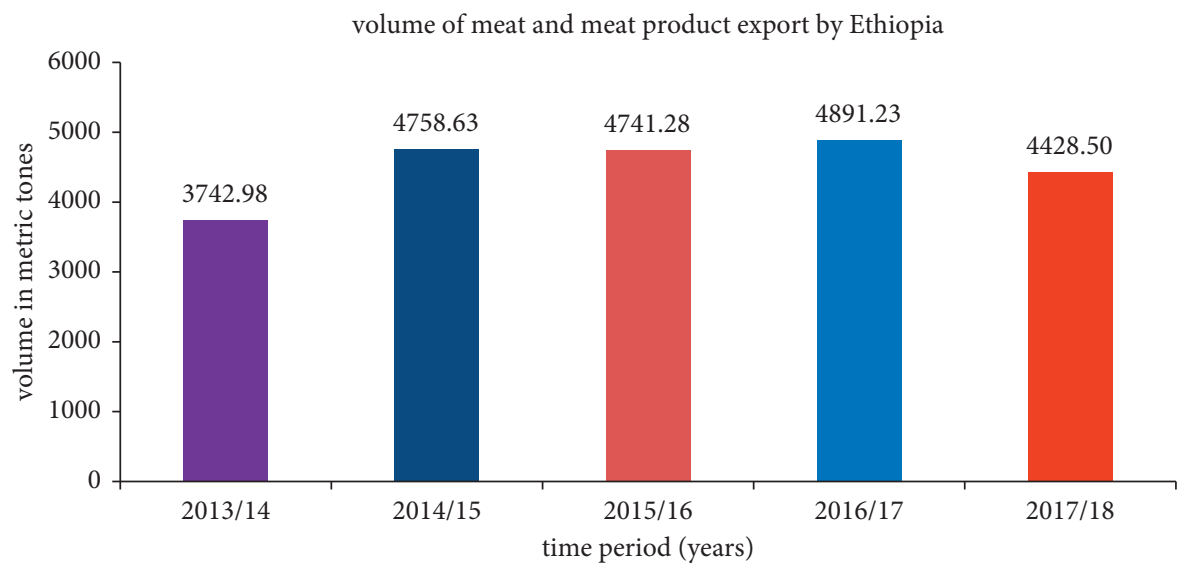

Figure 1: The volume of meat and meat products exported between 2013/14 and 2017/18. Source: [30].

contribution falls short of its potential, the livestock sector accounts for $15 \%$ of export revenues, 16.5 percent of national GDP, 30\% of agricultural employment, and 35.6 percent of agricultural GDP in Ethiopia's economy [5]. Ethiopians rely on beef cattle for revenue, food security, manure, investment, and foreign currency profits, as well as social and cultural identity.

In most agropastoral communities, livestock serves as the best asset for social activities. Cattle are utilized for dowering price, pride, and sacrifices for social events in the peripheral highlands and pastoral and agropastoral districts. Although most agricultural strategies are skewed towards crops for food security reasons, livestock is also an anchor for economic diversification and sustainable rural development. In Ethiopia, livestock is a primary source of income and food for the majority of rural people in pastoral and agropastoral farming systems due to the poor potential for crop development, particularly the lack of and/or restricted irrigation methods. Because of its various social, economic, and cultural applications, livestock ownership, in terms of both number and quality, is a valuable asset in this regard [32].

\subsection{Challenges for Pastoral Beef Cattle Production.} Pastoral beef cattle production in Ethiopia was severely limited by disease outbreaks, a lack of both quality and quantity of feed and water, a lack of veterinary services, the occurrence of droughts, a lack of market access and infrastructure, illegal live animal trades, and the genetic potential of indigenous cattle breeds.

2.2.1. Feed Shortage in Both Quality and Quantity. Natural grasses and agricultural leftovers, which have poor nutritional content and are not consistently supplied owing to seasonal fluctuations and drought, are the main feed resources for pastoral beef cattle farmers in Ethiopia [33, 34]. They may also differ among Ethiopia's various beef cattle production systems [35]. This could have a negative impact on the carcass production and beef quality of beef animals. In contrast, Dinku [18] stated that, during dry seasons, feed shortages and nutrient deficiencies are more severe.
According to Matawork [36], communal, uncontrolled, free, and private grazing grounds are the most available feed supply for pastoral beef cattle producers in many parts of the country. During the summer, however, these grazing fields turn muddy and are no longer suitable for grazing cattle. Crop wastes are also an important source of feed for pastoral farmers in the country during the dry season.

Similarly, Agegnehu et al. [22] found that feed scarcity for beef cattle is severe, in terms of both quality and quantity, notably in pastoral areas of Ethiopia, particularly in January and February. This could cause cattle cows' growth patterns to fluctuate and become erratic. Furthermore, both pastoral and agropastoral pastoral beef animal farmers use natural pasture grazing as their primary method of production. Due to overgrazing, this grazing ground is insufficient for beef cattle production, and it has seriously deteriorated and diminished from year to year [37]. Figure 2 depicts Ethiopia's key livestock feed resources and their proportions. According to the statistics, green fodder (grazing), agricultural leftovers, and hay are the main feed sources for pastoral farmers' cattle in Ethiopia. According to the statistics, the quality and supply of these resources vary periodically. This may have an impact on the country's beef production.

2.2.2. Water Shortage. During the dry season, water shortages, even if of low quality, are a major issue in many regions of the country, and the situation is exacerbated in pastoral areas where pastoral beef cattle producers have few wells, resulting in a variety of waterborne diseases in beef animals [34]. It is only available from wells and a few lakes and streams [38]. Similarly, pastoral beef animal producers walk with their cattle for more than 6-8 hours every day during dry seasons to find a source of water [39]. Animals' body weight, carcass yield, and quality decline as a result of this. Tolera and Abebe [38] and Kedija et al. [40] also showed that as the watering interval increases, the feed conversion efficiency of animals decreases. Similarly, Andualem et al. [34] found that poor water quality in cattle animals is linked to infections and helminth infestation, resulting in a lower carcass yield. 


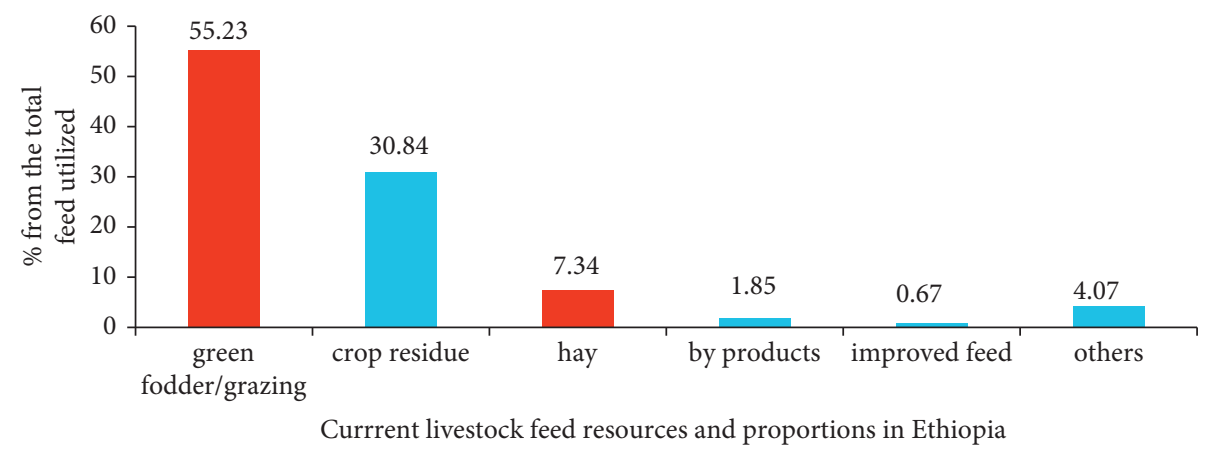

FIGURE 2: Current livestock feed resources and proportion in Ethiopia. Source: [1].

2.2.3. Diseases of Beef Cattle. Diseases have a variety of detrimental effects on herd productivity, such as animal death, weight loss, slowed growth, poor fertility performance, and physical weakness. Diseases have been combated in a variety of ways, including immunizations (preventive measures) and therapies (curative measures). Even though many experts throughout the world recommend proper preventive and $\mathrm{cu}-$ rative approaches, there is a paucity of scientific data on illness prevalence, immunizations, and therapies in Ethiopia, which makes fundamental disease prevention and control difficult [1]. Anthrax, foot and mouth disease (FMD), blackleg, lumpy skin disease (LSD), pasteurellosis, and parasites (both ecto and endo) were all major challenges in the beef cattle production sector and could be the cause of poor beef animal performance at any stage of pastoral production systems. Poorly fed beef animals, for example, have low disease resistance and fertility issues, resulting in low beef/meat production [41-43]. Physical contact between cattle animals brought from diverse locations via common pastures and watering as well as market areas, on the other hand, plays an essential role in the transmission of economically relevant infectious illnesses and parasites [44]. This may result in a reduction in animal tissue (muscle, fat, bone, and related tissues), resulting in poor quality and quantity of beef. Furthermore, according to Desta [45], beef animal diseases are the leading cause of economic and social losses among Ethiopian beef cow owners. This might have a significant detrimental impact on pastoral people, whose livelihood is entirely dependent on their livestock.

\subsubsection{Lack of Market Access, Infrastructure, and Illegal Trade.} Other important limiting constraints for the pastoral beef cattle production sector in Ethiopia include a lack of market access and infrastructure, as well as illicit trade or contraband live beef animal trades, which are not conducive to efficient cattle marketing. This could make it difficult for small-scale beef cattle farmers to remain profitable and active in the industry. Similarly, Tewodros and Mebrate [35] stated that, due to the lack of a nearby market, beef cattle producers are forced to travel long distances to sell their animals, resulting in significant body weight loss and animals being exposed to physical injuries and illness, resulting in a reduction in money available to cattle producers in particular and the country in general. This scenario is exacerbated in pastoral area communities where beef animal farmers lack access to current market information. As a result, producers may be vulnerable to market uncertainty, which could stymie the country's livestock industry. Ethiopia's legal system is dominated by illegal beef animal marketing methods [46]. This may reduce the country's export abattoirs' capacity to export high-quality beef animals or meat to neighboring nations, making them less competitive in the regional or global meat/beef market [47]. Furthermore, despite the fact that beef cattle production contributes to the county's economy and pastoral livelihood, the production system is not sufficiently market-oriented [23]. The annual migration of beef cattle from Ethiopia to other adjacent countries via the illegal market is substantial, as shown in Figure 3. Brokers, according to the graph, purchase directly from producers or fattening cooperatives. Small- and medium-scale exporters ship those animals legally, whereas small-scale exporters and farmers export them illegally, resulting in a shortfall of both live beef animals and beef for the country's legal exporters. This could have ramifications for small-scale beef cattle farmers as well as the country's livestock economy.

2.2.5. Lack of Veterinary Service. In many sections of the country, veterinary services are insufficient or unsatisfactory due to the lack of infrastructure and limited resources such as pharmaceuticals and veterinarians (people) [45, 48]. Because pastoral and low-land-area community beef cattle producers in the country are mobile, this may be overlooked. The lack of veterinarians (people), as well as a lack of inputs such as medications, vaccines, and equipment, was the key impediment to providing successful veterinary services to pastoral farmers [49]. The vast majority of Ethiopian beef cattle owners do not have access to curative and preventive services. Only a few public clinics with a small number of veterinarians are accessible in major cities, and they mostly serve cattle owners. These towns may completely overlook low-land and pastoral settlements. In general, animal health services are provided to only a few cattle farmers in and near towns in the country. This is mostly affecting the country's pastoral beef cattle output.

2.2.6. Lack of Improved Beef Cattle Breeds. According to CSA [50], Ethiopian indigenous beef cow breeds are suited to feed and water limitations, disease resistance, and hard temperatures. The output and productivity of indigenous beef animals, on the other hand, are quite low. Furthermore, Aynalem et al. [51] found that enhancing beef/meat output 


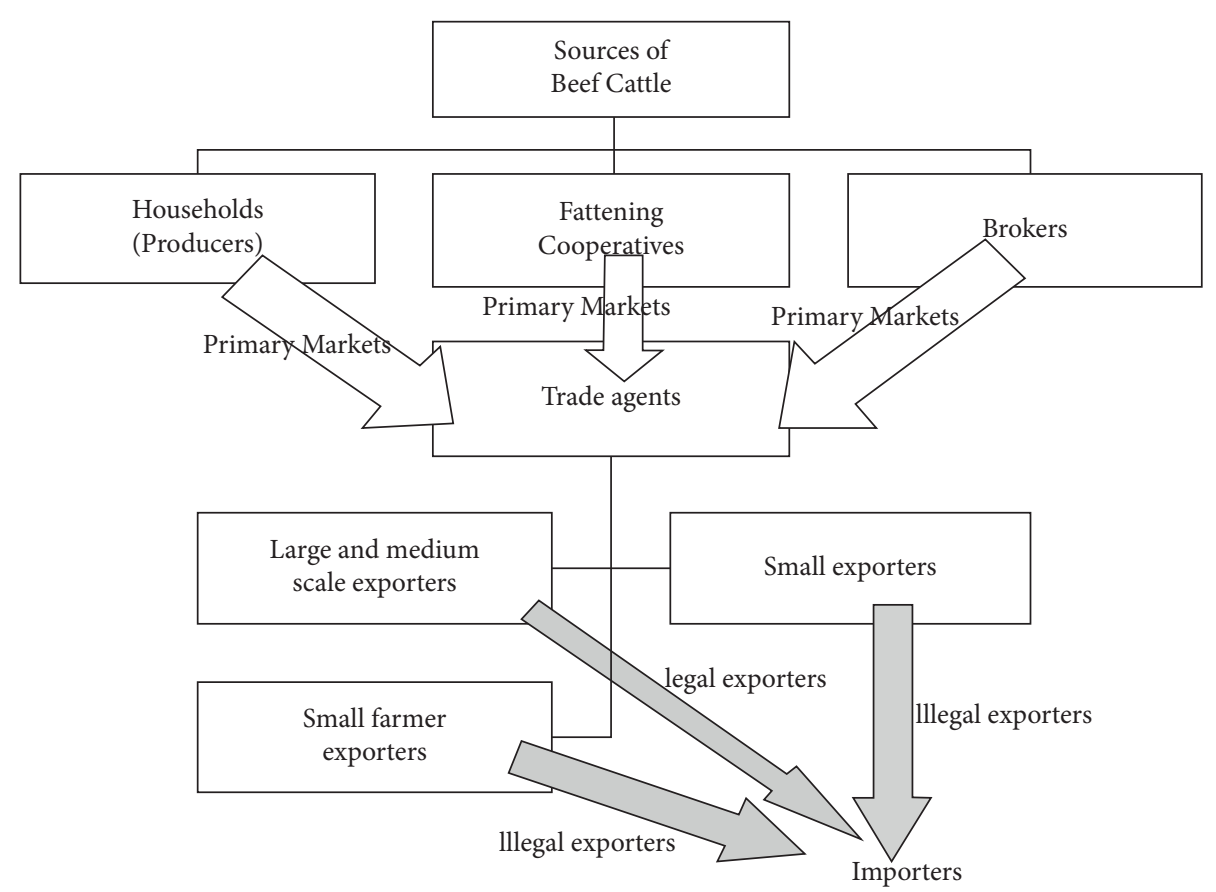

FIgURE 3: Beef cattle sources and market channel of trade in Ethiopia. Source: [21].

in the country has been unsuccessful due to little or no genetic improvement in recent decades. As a result, an effective and long-term beef animal genetic development plan for Ethiopia's indigenous beef cow breeds is required.

Ethiopian cattle breeds are divided into five categories: Humpless Brachyceros, Hamitic Longhorn, Zebu, Sanga, and intermediate between Sanga and Zebu, totaling 28 indigenous varieties. Although indigenous cattle can withstand hard weather, have strong disease resistance, and can adapt to a limited feed supply, their output per animal is poor [6]. The performance of cattle in terms of production and reproduction is a significant determinant factor in ensuring long-term livelihood improvement for individuals involved in the system. The Ethiopian livestock sector rarely employs technological adaptation since practically all livestock species are indigenous, and the fraction of hybrid livestock is too small, limiting average yields [52]. Improving the livestock industry in terms of quality and quantity is necessary in order to boost the export of leather and leather products, live animals, and livestock products such as leather and leather products, meat, and milk products. This can be aided by the production and use of genetically engineered plants and animals [53].

According to studies conducted by [54, 55], Ethiopia introduced exotic cattle breeds several decades ago (since the 1950s), mostly the Holstein Friesian breed, when the United Nations donated 300 Friesian and Brown Swiss dairy cattle to Ethiopia, which were also crossbred with the indigenous once. Several cattle productivity development projects have been conducted in Ethiopia for various reasons. In 1963, the first cow genetic improvement program was established with the goal of developing commercial dairy farms [54]. According to the CSA study, the majority of cattle reared by the agrarian community in Ethiopia are local breeds and ecotypes, accounting for 98.2 percent of total cattle in the country, with 1.62 percent being crossbred and 0.18 percent being exotic cattle breeds [31].

2.2.7. Incidence of Drought. Drought is one of the most significant limiting factors, particularly in the pastoral/lowland-area community beef animal production sector, as it causes a feed shortage and a water shortage, resulting in lower productivity and reduction in beef animal mature weight or longer time to reach mature weight [11]. According to the same authors, infestation of invasive species due to local weather change has limited the availability of herbaceous species, resulting in a necessary feed scarcity. According to Thornton et al. [38], drought has a negative impact on the results or availability of animal feed resources, which could have a significant impact on cattle animal productivity, feeding choices, and grazing management. The situation for pastoral beef cattle producers in arid and semiarid areas is dire.

Pastoral beef cattle production in Ethiopia was severely limited by disease outbreaks, a lack of both quality and quantity of feed and water, a lack of veterinary services, the occurrence of droughts, a lack of market access and infrastructure, illegal live animal trades, and the genetic potential of indigenous cattle breeds. In general, shortages of feed, diseases and parasites, lack of veterinary services, drought, lack of market access and infrastructure, and poor genetic potential of indigenous cattle breeds are the most recent major identified constraints of beef cattle production and fattening practice as expressed by farmers in various parts of the country, as shown in Table 1. 
TABLE 1: The recently identified constraints of beef cattle production/fattening practice in different parts of the country as expressed by farmers.

\begin{tabular}{|c|c|c|c|}
\hline Location in Ethiopia & Challenges & Rank & References \\
\hline \multirow{3}{*}{ East Shoa, Oromia } & Feed scarcity & 1 & \multirow{3}{*}[56]{} \\
\hline & Market fluctuation & 2 & \\
\hline & Diseases & 3 & \\
\hline \multirow{3}{*}{ Hadiya, southern } & Shortage of feed & 1 & \multirow{3}{*}[57]{} \\
\hline & Lack of good management & 2 & \\
\hline & Incidence of drought & 3 & \\
\hline \multirow{3}{*}{ Tigray, northern } & Shortage of feed & 1 & \multirow{3}{*}[58]{} \\
\hline & Shortage water & 2 & \\
\hline & Lack of market access & 3 & \\
\hline \multirow{3}{*}{ Somali, eastern } & Disease and absence of veterinary service & 1 & \multirow{3}{*}{ [59] } \\
\hline & Road for transportation & 2 & \\
\hline & Poor market information & 3 & \\
\hline \multirow{3}{*}{ Jimma, western } & Feed shortage & 1 & \multirow{3}{*}[60]{} \\
\hline & Market problem & 2 & \\
\hline & Disease & 3 & \\
\hline \multirow{3}{*}{ Omo, southern } & Lack of feed & 1 & \multirow{3}{*}{ [61] } \\
\hline & Incidence of drought & 2 & \\
\hline & Diseases and parasites & 3 & \\
\hline Burie, Amhara & Shortage of feed and water; limited knowledge; poor genetic potential of cattle & 123 & {$[62]$} \\
\hline
\end{tabular}

\section{Conclusions}

The purpose of this review was to collate the opportunities and challenges for pastoral beef cattle production in Ethiopia. The rapid growth of the Ethiopian population, urbanization, literacy, and family income, as well as the high demand for live beef animals and red meat by domestic abattoirs and other countries, were among the prospects or potentials for pastoral beef cattle producers. Traditional beef cattle production systems, diseases, lack of feed and water, lack of veterinary services, drought, lack of market and infrastructure, illegal trades, and the genetic potential of indigenous cattle breeds were among the main hindrances to Ethiopian beef cattle production being sustainable and successful. Furthermore, while pastoral beef cattle producers in Ethiopia were not considered a small business segment, and the majority of beef came from old oxen kept for draft purposes, culled cows, and surplus young bulls, the level or quality of beef produced in Ethiopia is lower than that in the market of other East African countries and the global market in general. The following suggestions are made based on the aforesaid conclusion:

(i) To alleviate the serious shortage of animal feed in Ethiopia, the government should pay special attention to pastoral farmers' cattle production and establish a framework for introducing, adapting, and growing improved or drought-resistant forages or grass species

(ii) The responsible body should provide knowledge and skill-based training for pastoral beef cattle producers and create awareness for them to engage in different beef cattle fattening operations that may improve their production systems in collaboration with all the agricultural sectors of the country (iii) Sustainable pastoral beef cattle production with a defined market destination or a strong market linkage with other market chain sectors should be established by the government of Ethiopia in order to reduce the amount of money lost to the country illicit or contraband live beef cattle merchants

(iv) The genetic makeup of country beef cattle breeds should be improved by crossbreeding with exotic cattle breeds, as well as pastoral beef cattle production systems

(v) Affordable community-based animal health service delivery, encompassing pastoral and rural populations, should be implemented, as this may increase Ethiopia's beef production competitiveness in contrast to other East African countries
Abbreviations
CSA: Central Statistical Agency
FAO: Food and Agricultural Organization
FMD: Foot and mouth disease
GDP: Growth domestic product
LSD: Lumpy skin disease.

\section{Data Availability}

The document used to support the review of this paper is available from the corresponding author upon reasonable request.

\section{Conflicts of Interest}

There are no conflicts of interest related to the publication of this review manuscript. 


\section{References}

[1] CSA [Central Statistical Agency], Agricultural Sample Survey: Livestock and Livestock Private Peasant Characteristics Report, Volume II, Statistical Bulletin 587, Central Statistical Agency (CSA), Addis Ababa, Ethiopia, 2020.

[2] F. Terefe, The Impact of the Export of Live Animals on the Meat Processing Firms and Foreign Exchange Earnings to the Economy of Ethiopia 2008, AAU Institutional Repository, Fitta, Ethiopia.

[3] FAO [Food and Agricultural Organization], Analysis of Price Incentives for Live Cattle in Ethiopia, Technical Notes Series, FAO, Rome, Italy, 2015.

[4] B.M. Getachew Keredin, "Characterization of beef cattle production systems in tropics, the case of Ethiopia a review," International journal of animal science, husbandry and livestock production, vol. 6, no. 9, pp. 354-360, 2020.

[5] D. Duressa, D. Kenea, W. Keba et al., Assessment of Livestock Production System and Feed Resources Availability in Three Villages of Diga District Ethiopia 2014, CGIAR, Diga, Ethiopia.

[6] E. BI. Ethiopian, National Strategy and Plan of Action for Conservation and Utilization of Animal Genetic Resources Ethiopian Biodiversity Institute (EBI), EBI, Addis Ababa, Ethiopia, 2016.

[7] Z. Girma, "Bringing livestock development Actors into a uni platform," in Proceedings of the Cahnet-ethiopia Launching Workshop, Addis Ababa, Ethiopia, April 2010.

[8] A. Agus and T. S. Mastuti Widi, "Current situation and future prospects for beef cattle production in Indonesia-a review," Asian-Australasian Journal of Animal Sciences, vol. 31, no. 7, pp. 976-983, 2018.

[9] S. Gebremariam, S. Amare, D. Bake, and A. Solomon, Diagnostic Study of Live Cattle and Beef Production and Marketing, Constraints and Opportunities for Enhancing the System, CGIAR, Washington, DC, USA, 2010.

[10] S. Gebremariam, S. Amare, D. Baker, and A. Solomon, Davies $R$ Study of the Ethiopian Live Cattle and Beef Value Chain, International Livestock Research Institute, Nairobi, Kenya, 2013.

[11] A. Yitage, "Characterization and analysis of the urban and per urban and dairy production system in the north western Ethiopian high-land," Acad. J. Nutr.vol. 2, no. 3, p. 120, 2007.

[12] A. Abbey, Red Meat and Poultry Production and Consumption in Ethiopia and Distribution in Addis Ababa, M. Sc thesis, Addis Ababa University, Addis Ababa, Ethiopia, 2010.

[13] T. Eshetie, K. Hussien, T. Teshome, and A. Mekonnen, "Meat production, consumption and marketing tradeoffs and potentials in Ethiopia and its effect on GDP growth: a review," Journal of Marketing and Consumer Research, vol. 42, pp. 17-24, 2018.

[14] M. Upton, "The role of livestock in economic development and poverty reduction, pro-poor livestock policy initiative," PPLPI Working, 2016.

[15] N. Gebreselassie, "Review on beef cattle production and marketing system in Ethiopia," Journal of Fisheries Livest Product, vol. 6, p. 277, 2018.

[16] H. Ritchie, Which Countries Eat the Most Meat?, BBC News, London, UK, 2019.

[17] T. Daniel, "Beef cattle production system and opportunities for market orientation in Borena zone, Southern Ethiopia," A Thesis Submitted to the Department of Animal Science, School of Graduate Studies Haramaya University, Dire Dawa, Ethiopia, 2008.
[18] A. Dinku, "Assessment of constraints and opportunities in small-scale beef cattle fattening business: evidence from the West Hararghe Zone of Ethiopia," International Journal of Veterinary Sciences Research, vol. 5, no. 2, pp. 058-068, 2019.

[19] B. Shapiro, G. Gebru, S. Desta et al., Ethiopia Livestock Sector Analysis: A 15 Year Livestock Sector Strategy 2017, ILRI (International Livestock Research Institute), Nairobi, Kenya.

[20] M. Siegmund-Schultze, G. Legesse, G. Abebe, and A. Zárate, "Bottleneck analysis of sheep production systems in southern Ethiopia: comparison of reproductive and growth parameters," Options Méditerranéennes. Changes in Sheep and Goat Farming Systems at the Beginning of the $21^{\text {st }}$ Century, CIHEAM-IAMZ, Zaragoza, Spain, 2009.

[21] P. Reddy and N. Kanna, "Market and value chain analysis of cattle and beef in Ethiopia-a review," International Journal of Social Sciences, Arts and Humanities, vol. 1, no. 2, 2015.

[22] M. Agegnehu, A. Biruk, and H. Haymanot, "Assessment on challenges, opportunities and associated health problems of Beef Cattle production systems in Hawassa, Southern Ethiopia," International Journal of Advanced Research in Biological Sciences, vol. 5, no. 11, pp. 103-113, 2018.

[23] S. Sintayehu, "A review of challenges and opportunity of livestock marketing in southern part of Ethiopia," Journal of Marketing and Consumer Research (An International Peerreviewed Journal), vol. 34, pp. 1-4, 2017.

[24] FAO, The State of Food Security and Nutrition in the World 2018. Building Climate Resilience for Food Security and Nutrition, FAO, Rome, Italy, 2018.

[25] UN World Population Prospects, The 2017 Revision, Key Findings and Advance Tables, UN World Population Prospects, New York, NY, USA, 2017.

[26] P. K. Thornton, "Livestock production: recent trends, future prospects," Philosophical Transactions of the Royal Society B: Biological Sciences, vol. 365, no. 1554, pp. 2853-2867, 2010.

[27] S. Ameha, Export Requirements for Meat and Live Small Ruminants: How Can Development Agents Assist Producers to Improve Small Ruminant Export? Technical Tulletin No.47, ESGPIP, Addis Ababa, Ethiopia, 2011.

[28] E. Tekeba and H. Kelifa, "Tadesse T and Abebaw M Meat production, consumption and marketing tradeoffs and potentials in Ethiopia and its effect on GDP growth: a review," Journal of Nutritional Health and Food Engineering, vol. 8, no. 3, pp. 228-233, 2018.

[29] A. Kefyalew, "Value chain assessment of beef cattle production and marketing in Ethiopia: challenges and opportunities of linking pastoral farmers to the markets," Livestock Research for Rural Development, vol. 23, no. 12, 2011.

[30] P. Thornton, M. Herrero, A. Freeman et al., "Vulnerability, climate change and livestock-research opportunities and challenges for poverty alleviation," Climate Change, vol. 4, no. 1, 2007.

[31] CSA [Central Statistical Agency], Agricultural Sample Survey: Livestock and Livestock Characteristics Report, Volume II, Statistical Bulletin 585, Central Statistical Agency (CSA), Addis Ababa, Ethiopia, 2017.

[32] A. Aleme and Z. Lemma, "Contribution of livestock sector in Ethiopian economy: a review," Advances in Life Science and Technology, vol. 29, pp. 79-90, 2015.

[33] T. Adugna, Feed Resources and Feeding Management. A Manual for Feedlot Operators and Development Workers. Addis Ababa, Ethiopia, pp. 8-35, FAO, Rome, Italy, 2008.

[34] T. Andualem, T. Berhan, G. Gebeyehu, and B. Ermias, "Characterization of cattle husbandry practices in essera 
woreda, dawuro zone, southern Ethiopia," African Journal of Agricultural Research, vol. 10, no. 34, pp. 3421-3435, 2015.

[35] A. Tewodros and G. Mebrate, "Beef cattle production systems, challenges and opportunities in Ethiopia," JOJ Pub Health, vol. 5, no. 1, pp. 1-5, 2019.

[36] M. Matawork, "Beef cattle production systems, marketing and constraints in Ethiopia," Journal of Marketing and Consumer Research, vol. 32, pp. 1-7, 2017.

[37] A. Sora, "Borena range land and today's situation," in ESAP Newsletter issue No 13ESAP, Hyderabad, India, 2006.

[38] A. Tolera and A. Abebe, "Livestock production in pastoral and agro-pastoral production systems of southern Ethiopia," Livestock Research for Rural Development, vol. 19, no. 12, pp. 4-7, 2007.

[39] Care-Ethiopia, CARE-Ethiopia Has Contracted Out YONAD Business Promotion and Consultancy Service in May 2009 to Analyze the Milk and Milk Products Value Chain in Borana Pastoral Community, Care-Ethiopia, Addis Ababa, Ethiopia, 2009.

[40] H. Kedija, T. Azage, Y. Mohammed, and G. Berhanu, “Traditional cow and camel milk production and marketing in agro-pastoral and mixed crop-livestock systems: the case of mieso district, oromia regional state, Ethiopia," (IPMS) Improving Productivity and Market Success of Ethiopian Farmer, Project Working Paper, 13, vol. 56, pp. 1-3, ILRI (International Livestock Research Institute), Nairobi, Kenya, 2008.

[41] H. Ayalew, G. Tamru, and D. Abebe, "Beef cattle fattening practices and marketing systems in gondar town, amhara, Ethiopia," Journal of Veterinary Science \& Technology, vol. 9, p. 555, 2018.

[42] H. Belachew and M. Mebratu, "Beef cattle fattening practices, constraints and future potentials in Ethiopia: a review," Animal Research International, vol. 16, no. 2, pp. 3401-3411, 2019.

[43] A. Belete, T. Azage, B. Fekadu, and G. Berhanu, "Cattle milk and meat production and marketing systems and opportunities for market-orientation in Fogera woreda, Amhara region, Ethiopia," IPMS (Improving Productivity and Market Success) of Ethiopian Farmers Project Working Paper 19, pp. 55-65, ILRI (International Livestock Research Institute, Nairobi, Kenya, 2010.

[44] J. Kula, A. Nejash, and A. Jemal, "Insufficient veterinary service as a major constrants in pastoral area of Ethiopia: a review," Journal of Biology, Agriculture and Healthcare, vol. 6, no. 9, pp. 94-101, 2016.

[45] A. Desta, "Major constraints of veterinary services delivery system and its solution in pastoral areas of Ethiopia," International Journal of African and Asian Studies, vol. 12, 2015.

[46] M. Elias, E. Mulugeta, B. Gebremedhin et al., "Analysis of the ethio-Sudan cross-border cattle trade: the case of amhara regional state," IPMS (Improving Productivity and Market Success) of Ethiopian Farmers Project Working Paper 4, ILRI (International Livestock Research Institute), Nairobi, Kenya, 2007.

[47] C. Filip, Ethiopian Borena and Southern Somali Areas Livestock Value Chain Analysis Report, ACDI/VOCA Pastoralist Livelihood Initiatives Livestock Marketing Project, 2006.

[48] H. Angesom, "Major constraints of veterinary services delivery system and its solution in pastoral areas of Ethiopia," International Journal of African and Asian Studies, vol. 12, pp. 5-11, 2015.

[49] J. Tariku, M. Ashenafi, and G. Kidane, "Assessment of veterinary services in central Ethiopia: a case study in ada' a district of oromia region, Ethiopia," Ethiopian Veterinary Journal, vol. 19, no. 2, pp. 1-9, 2015.

[50] CSA [Central Statistical Authority], Agricultural Sample Survey 2008/2009, Volume II Report on Livestock and Livestock Characteristics (Private and Peasant Holdings) Statistical Bulletin 446, Central Statistical Agency (CSA), Addis Ababa, Ethiopia, 2009

[51] H. Aynalem, A. Workneh, K. Noah, D. Tadelle, and T. Azage, "Breeding strategy to improve Ethiopian Boran cattle for meat and milk production," Improving Productivity and Marketing Success of Ethiopian Farmers. Project Working Paper 26. ILRI, pp. 37-45, International Livestock Research Institute, Nairobi, Kenya, 2011.

[52] H. Berhane, "Ethiopian cattle genetic resource and unique characteristics under a rapidly changing production environment-a review," International Journal of Science and Research, vol. 6, no. 12, pp. 1959-1968, 2017.

[53] M.S. Bezabih Falco and A. Mekonnen, "Is it the climate or the weather? Dierential economic impacts of climatic factors in Ethiopia," Centre for Climate Change Economics and Policy, Working Paper No. 165, Grantham Research Institute on Climate Change and the Environment Working.

[54] C. Chebo and K. Alemayehu, "Trends of cattle genetic improvement programs in Ethiopia: challenges and opportunities," Livestock Research for Rural Development, vol. 24, Article ID 109, 2012.

[55] L. Habtamu, B. Kelay, and S. Desie, "Study on the reproductive performance of Jersey cows at wolaita sodo dairy farm, southern Ethiopia," Ethiopian Veterinary Journal, vol. 14, no. 1, pp. 53-70, 2010.

[56] G. Dadi, M. Urge, and T. Teklebrhan, “Assessment of commercial beef cattle fattening practices and performance in East Shoa Zone," International Journal of Agricultural Science and Food Technology, vol. 3, no. 3, pp. 67-76, 2017.

[57] K. Amistu, E. Nigatu, and A. Handiso, "Assessment of livestock feed resources and improved forage management practices in Gibe district of Hadiya Zone, southern Ethiopia," Journal of Biotechnology, Agricultural and Health, vol. 7, no. 3, pp. 72-77, 2017.

[58] T. Gebremichael, T. T. Gebrewahd, and N. Kumar, "Assessment of beef cattle fattening practices and its challenges in and around Mekelle, Tigray, Ethiopia," Ethiopian Veterinary Journal, vol. 21, no. 1, pp. 29-39, 2017.

[59] S. Fikru, "Assessment of cattle fattening and marketing practice in harshin district of Somali regional state, Ethiopia," Advances in Dairy Research, vol. 3, no. 2, Article ID 1000137, 2015.

[60] Z. Worku, S. Tilahun, T. Tolemariam, and W. Jimma, “Assessment of the prevailing cattle fattening practices in Jimma Zone, South-Western Ethiopia," Global Veterinaria, vol. 17, no. 2, pp. 105-113, 2016.

[61] Y. Alemayehu, A. Adicha, M. Mengistu, and B. Eshetu, "Assessments of market Oriented beef cattle fattening System under farmer management condition in South Omo zone of SNNPR," Current Research in Agricultural Sciences, vol. 3, no. 3, pp. 31-45, 2016.

[62] G. Belay and T. Negesse, "Feed resource availability and their nutrient contribution for livestock evaluated using feed assessment tool (FEAST) in Burie Zuria District, North Western Ethiopia," Agricultural Research and Technology, vol. 17, no. 3, 2018. 